
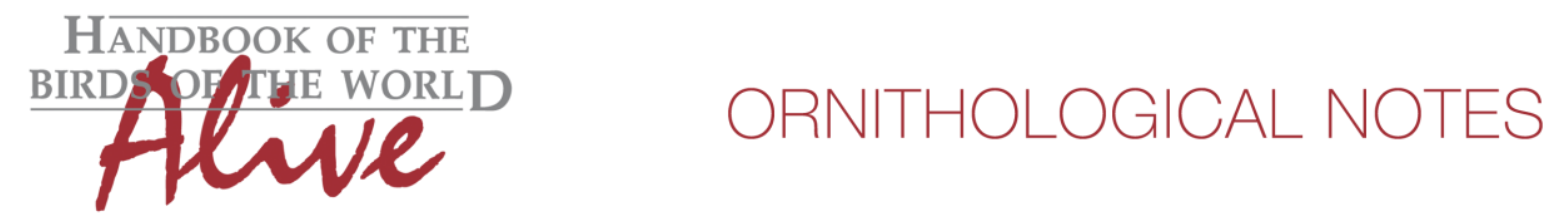

\title{
Notes on the vocalizations of Lesser Woodcreeper (Xiphorhynchus fuscus)
}

Peter Boesman

In the following we briefly analyze and compare voice of the different races of Lesser Woodcreeper (Xiphorhynchus fuscus). We also try to quantify the extent of any vocal differences using the criteria proposed by Tobias et al. (2010), as a support for taxonomic review. We have made use of sound recordings available on-line from Xeno Canto (XC).

Voice in general is quite variable, the more extensive vocalizations can be considered 'full loudsong', but there are also shorter versions which are either a 'short song' or a 'long call', but it is not clear whether these vocalizations have a different function.

From a screening of the available recordings, it would seem that there are 3 vocal groups (no recordings for sure of brevirostris, as exact boundaries of this taxon not well-defined):

\section{atlanticus}

Typical song is a fast series of notes, usually starting with only a few slower notes (sometimes none), then shifting immediately to a fast series of notes (which may initially go down in pitch and/or go up in pitch again), and slowing down slightly towards the end (Fig. 1). Pace quite variable, sometimes very fast, sometimes less so.

Measurements:

$\begin{array}{ll}\text { max. freq. } & 3570-5050 \mathrm{~Hz} \\ \text { max. pace } & 0.05-0.086 \mathrm{~s} \\ \text { min. note length } & 0.04-0.05 \mathrm{~s} \\ \text { max. note length } & 0.06-0.08 \mathrm{~s} \\ \text { total length } & 2.28-3.55 \\ \text { \# of notes } & 21-47 \\ \text { length first } 5 \text { notes } & 0.20-0.80 \mathrm{~s} \\ \text { length last } 5 \text { notes } & 0.51-0.90 \mathrm{~s}\end{array}$

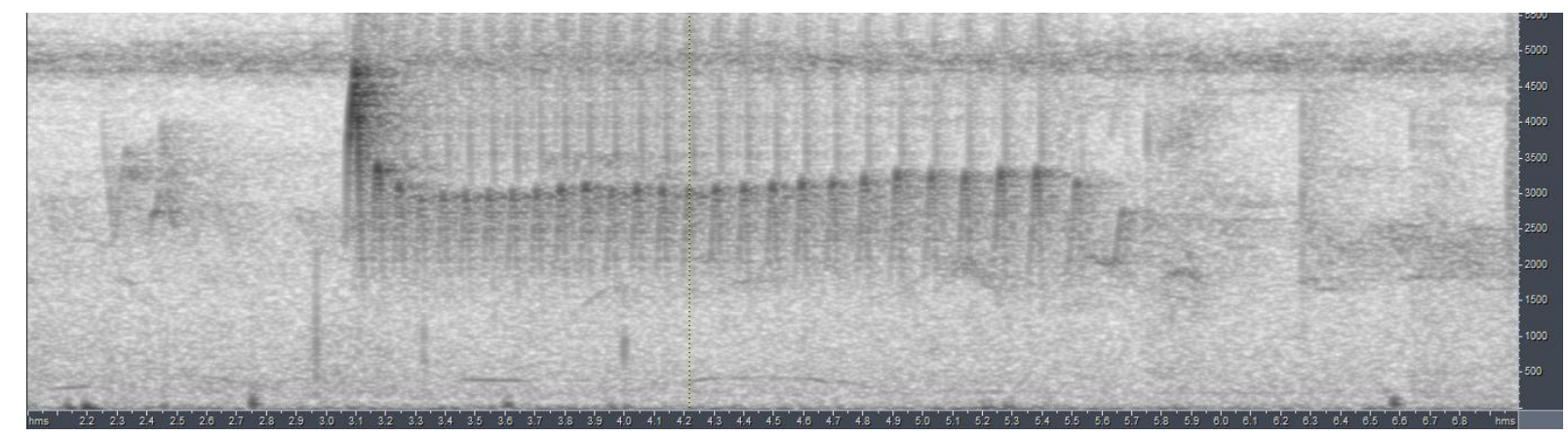

Figure 1: typical song of atlanticus 

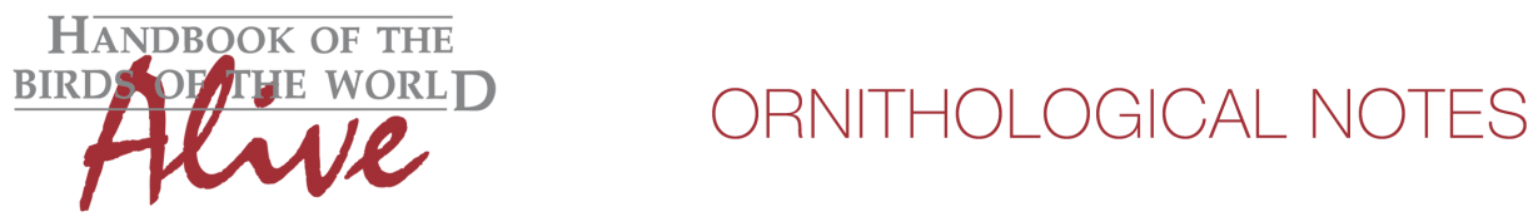

\section{tenuirostris}

Song apparently a descending series of rather slowly delivered notes, without clear acceleration/deceleration (Fig. 2). Very different from other taxa. Note shape is rather irregular.

Measurements:

max. freq.

$3500-4420 \mathrm{~Hz}$

max. pace

$0.11-0.21 \mathrm{~s}$

min. note length

$0.07-0.10 \mathrm{~s}$

max. note length

$0.14-0.24 \mathrm{~s}$

total length

2.33-3.60s

\# of notes

$11-18$

length first 5 notes

$0.47-1.12 \mathrm{~s}$

length last 5 notes

$0.90-1.18 \mathrm{~s}$

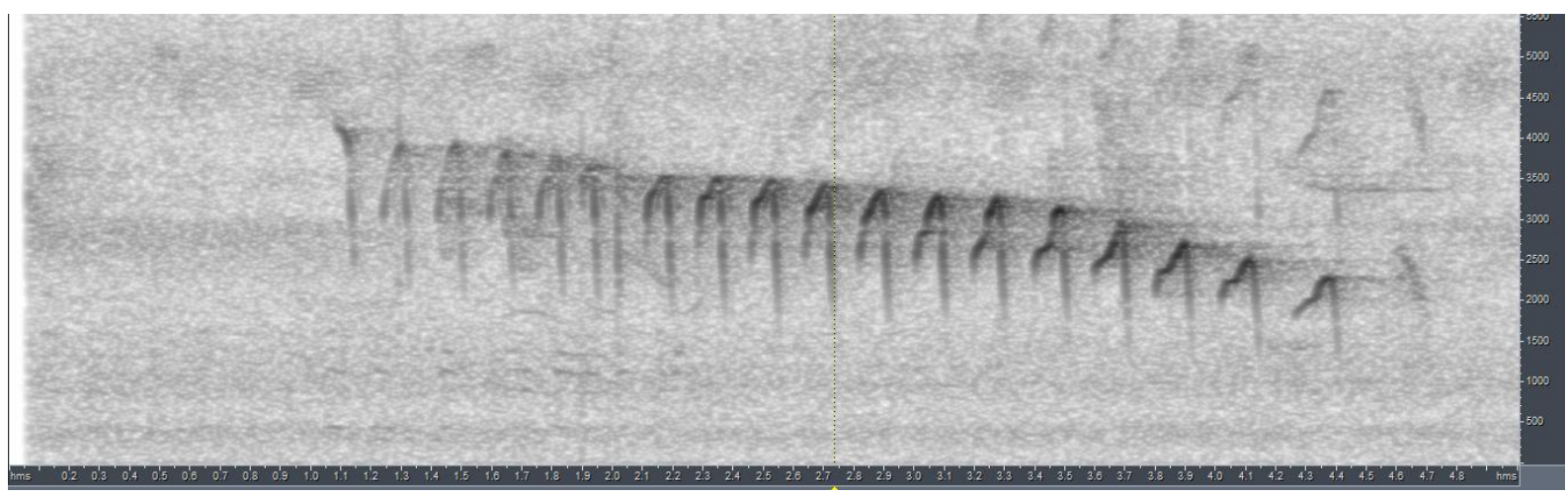

Figure 2: typical presumed song of tenuirostris

\section{fuscus}

Typical song quite diagnostic: a series of slowly delivered notes at stable pitch, gradually accelerating into a fast series which goes down and up again in pitch, slowing down towards the end. Some shorter vocalizations of fuscus (short song or long call??) are however less typical, and could be confused with atlanticus (Fig. 3). Such vocalizations seem to be the most common in the northern part of the fuscus range, and less so in the southern part (the transition occurring somewhere between Rio De Janeiro and Sao Paulo.

Measurements:

max. freq.

$3800-4920 \mathrm{~Hz}$

max. pace

$0.06-0.14 \mathrm{~s}$

min. note length

$0.04-0.08 \mathrm{~s}$

max. note length

$0.07-0.09 \mathrm{~s}$

total length

2.44-6.61s

\# of notes

16-31

length first 5 notes

1.08-1.75s

length last 5 notes

$0.48-1.56 \mathrm{~s}$ 


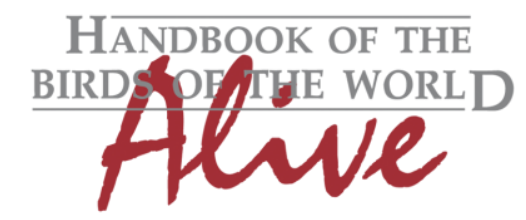

\section{ORNITHOLOGICAL NOTES}

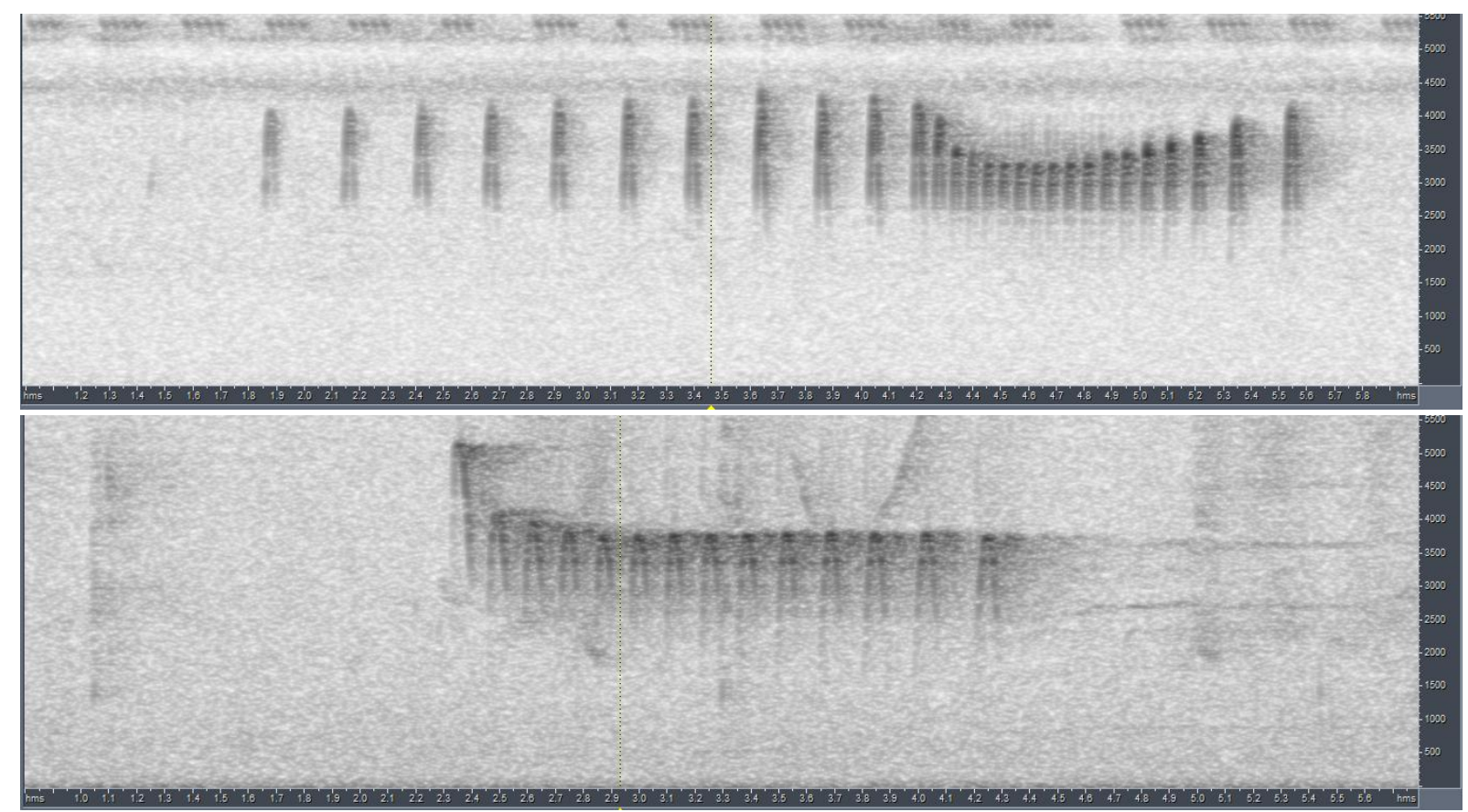

Figure 3: typical song of fuscus (top) and shorter version (bottom)

It is clear from the above that vocally tenuirostris is the most distinct taxon. It differs from the other taxa by much longer notes (score 2-3) which are fewer in number (score 1-2), having a stable pace (score 2), and a consistently descending series of notes (score 1) with irregular note shape (score 1 ). This would lead to a total vocal score of about 5 when applying Tobias criteria.

atlanticus and fuscus are much less differentiated. atlanticus has however typically a faster pace (score 1), lacks the long series of well-spaced introductory notes as in typical fuscus (expressed as length of first 5 notes, even in 'short songs' of fuscus a notable difference, but then it is in fact again measurement of pace and should thus not be cumulated with faster pace, score 2 ). This leads to a total score of about 2.

It would thus seem that vocal divergence of geographically intermediate tenuirostris is most outspoken. This is quite an unusual outcome, and a possibility is that this population is an effective barrier for gene flow between fuscus and atlanticus.

This note was finalized on 28th August 2015, using sound recordings available on-line at that moment. We would like to thank in particular the many sound recordists who placed their recordings for this species on XC.

\section{References}

Tobias, J.A., Seddon, N., Spottiswoode, C.N., Pilgrim, J.D., Fishpool, L.D.C. \& Collar, N.J. (2010). Quantitative criteria for species delimitation. Ibis 152(4): 724-746. 


\section{Recommended citation}

Boesman, P. (2016). Notes on the vocalizations of Lesser Woodcreeper (Xiphorhynchus fuscus). HBW Alive Ornithological Note 86. In: Handbook of the Birds of the World Alive. Lynx Edicions, Barcelona. (retrieved from http://www.hbw.com/node/931980 on 18 July 2016). 